UDC: 355.48(439-89:475)"1340"

Ђура Харди

Универзитет у Новом Саду

Филозофски факултет

Одсек за историју

hardyg@ptt.rs
Оригиналан научни рад

примљено: 22. март 2013

прихваћено: 1. октобар 2013

\title{
ХРОНОЛОГИЈА ЈЕДНОГ ПОХОДА ПАЛАТИНА ВИЉЕМА ДРУГЕТА*
}

Сажетак: У раду се на основу анализе итинерарских података из публикованих судских повеља истражује хронологија похода угарског палатина Виљема Другета на Галичко-волинску кнежевину 1340. године. Поход је био предузет као војна помоћ пољском краљу Казимиру III Великом коју је упутио његов савезник и рођак, угарски краљ Карло Роберт Анжујски, с циљем да се освоје поменуте руске земље после смрти њиховог владара Јурија II Болеслава. Такође аутор рада покушава да одреди дужину трајања угарског ратовања на руском тлу, као и могућу снагу угарске краљевске војске којом је заповедао један представник породице Другет. Другети су, наиме, под својом заставом у претходном периоду водили војске у походе на Србију, Хрватску, Прусију. Пољска.

Кључне речи: Виљем Другет, војни поход 1340, Угарска, Галиција и Волинија,

Почетак војног ангажовања анжујске династије и Угарске у борби за наследство Романовича обележен је једним походом угарског палатина Виљема Другета. Овај податак је, такорећи, одавно постао опште (познато) место у историографији. Покрет угарске краљевске војске под командом Другета 1340. године на Галичко-волинску државу историчари су једногласно повезали с најмање две важне политичке околности: С недавним угарско-пољским династичким савезом склопљеним у Вишеграду (1339) и бурним збивањима на руском тлу током те, 1340, године. ${ }^{1}$

\footnotetext{
* Текст је настао као фазни резултат рада на пројекту Војвођански простор у контексту европске историје (број 177002) Министарства просвете, науке и технолошког развоја Републике Србије и пројекту Средњовековна насеља на тлу Војводине. Историјски прочеси и догађаји (бр. 114-4512216/2011), који финансира Покрајински секретаријат за науку Владе Аутономне Покрајине Војводине.

${ }^{1}$ Михайло Грушевський, Історія України-Руси, III-IV, Київ 1993, passim; Jan Dąbrowski, Ostatni lata Ludwika Wielkiego 1370-1382, Krakow 2009, 86-94; Henryk Paszkiewicz, Polityka ruska Kazimierza Wielkiego, Warszawa 1925, 46-87; Károly Róbert emlékezete (A szöveg anyagot válogatta, szerkesztette, a bevezetőt és a jegyzeteket írta Kristó Gyula és Makk Ferenc, A képanyagot Marosi Ernő válogatta), Budapest
} 
Наиме, 7. априла (или 25. марта) био је отрован владар Галичко-волинске државе Јуриј II Болеслав Тројденович, по женској линији последњи представник династије Романовича. По казивању пољских хроничара, пољски краљ Казимир III Велики је изгледа већ око 16. априла предузео свој први поход на земље Романовича, по свему судећи с циљем да након њиховог освајања постане наследник свог рођака Јурија Болеслава. Пољаци су тада заузели престоницу Лавов, похарали кнежевску ризницу и с пленом се убрзо повукли. Међутим, Казимир је у јуну (око 24. јуна), с већим снагама поновио поход на руске земље. Насупрот претензијама пољског краља у међувремену се организовала волинска и галичка бојарска елита. Уздајући се у помоћ Монгола, за свог новог владара бојари су признали литванског кнеза Лумбарта Димитрија. Био је то увод у дуготрајни сукоб за наследство Романовича. Дакле, поход Виљема Другета без сумње је представљао помоћ коју је угарски краљ Карло Роберт упутио свом савезнику и рођаку, брату своје супруге Елизабете, пољском краљу Казимиру, у борби за галичко-волинске земље. А чак не би требало искључити ни могућност да је на планирање ове угарске војне кампање, која се поклопила с убиством Јурија Болеслава, утицао руско-монголски упад у пољске и угарске територије, фебруара 1340. године.

У претходном периоду били смо у прилици да истражујемо историју породице Другет у Угарској и земљама њеног порекла, Напуљској краљевини и Француској. Самим тим дотакли смо се и похода Виљема Другета из 1340. године. Уважавајући сазнања наших цењених претходника, овом приликом покушали бисмо да дамо неколико нових напомена о реченом походу. Пре свега, оне напомене које се односе на хронологију и војни потенцијал угарског контингента.

Заправо, о учешћу Виљема Другета и угарске војске у збивањима на тлу руских, тј. украјинских земаља (in Ruteniam) 1340. године, непосредно, говори само један документ. Иако је он добро познат историографији, због његовог значаја ред је да га поново прикажемо. По среди је било уобичајено одлагање једног суђења. Јудекс краљевске курије Пал Нађмартони је 15. маја 1340. године по наредби краља одложио један судски спор између представника племићких породица Розгоњи и Шашвари, првобитно заказан за 8. мај. Учињено је то због тога што су се два члана породице Розгоњи: Петер, син Ладислава, и Ладислав, син Јаноша, налазили „...in quadam expedicione regni nostri proficua in Ruteniam unacum Wyllermo palatino...". Парница је била одложена на уобичајених петнаест дана од завршетка краљевског похода. ${ }^{2}$

1988 (= Kristó-Makk, Károly Róbert emlékezete), 47; Jerzy Wyrozumski, Kazimierz Wielki, WrocławWarszawa-Kraków 2004, 69-70; Мирослав Волощук, Андрій Стасюк, Про похід палатина Віллерма іn Ruteniam у квітні 1340 p. Вісник Прикарпатського університету, Історія, Випуск 17, 1995, 46-54; Leontyj Wojtowycz, Walka o spadek po Romanowiczach a król polski Kazimierz III Wielki, Kazimierz Wielki i jego państwo (ed. J. Maciejewski, T. Nowakowski), Bydgoszcz 2011, 47-66.

${ }_{2}^{2}$ Anjoukori okmánytár, Codex diplomaticus Hungaricus Andegavensis (Szerkesztik Imre Nagy, Gyula Tasnádi Nagy), I-VII, Budapest 1878-1920 (= A), III, 26-27; За хронологију документа: Mór Wertner, Magyar hadjáratok a XIV. században, Századok (= Sz), 1905, 436. Неспорна је чињеница да у овом походу Карло Роберт није лично учествовао. То недвосмислено потврђује његов итинерариј: Ferdo Šišić, Itinerarij Karla I(1301-1342), Vjesnik Kraljevskog-slavonsko-dalmatinskog Zemaljskog Arkiva, 1902, 142. 
На основу овог извора историчари су приступили одређивању хронологије угарског похода, логично се махом задржавајући на месецу мају као термину његовог одвијања. Антал Пор је сматрао да је поход покренут пре косидбе, ${ }^{3}$ а увек поуздани Мор Вертнер - да је била реч о походу после 15. маја. ${ }^{4}$ Михајло Грушевски је констатовао да се угарска војска у првој половини маја налазила на походу у Галичини који је био започет пре 7. маја. У свом раду он се притом осврнуо и на ставове два ранија аутора: Антонија Прохаске и Омељана Тарлецког. ${ }^{5}$ Обојица су, наиме (добро је приметио Грушевски), погрешно сматрала да је војску лично предводио угарски краљ, с тим да је Терлецки закључио да је угарска војска кренула на „Рус“, тачно, 7. маја, док је његов претходник Прохаска одвијање угарског

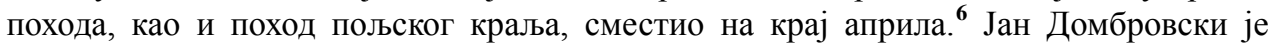
закључио да је угарска витешка војска под вођством палатина Виљема Другета у мају већ ратовала на Казимировој страни. ${ }^{7}$ Јиржи Вирозумски саопштава да је угарска војна помоћ у руске земље стигла између првог и другог Казимировог похода (између 16. априла и 24. јуна). ${ }^{8}$ Нажалост, рад Анатола Левицког посвећен овој проблематици остао нам је недоступан. ${ }^{9}$ У најновије време Мирослав Волошчук и Андреј Стасјук написали су посебан рад посвећен Виљемовом походу који нам је, признајемо, био од велике помоћи. По њима, поход се збио током априла-маја, а сама угарска војска је покренута 19 , односно 20 . априла. ${ }^{10}$

Ипак, чини нам се да бисмо кроз анализу итинерарија главнокомандујућег угарске војске, палатина Виљема Другета, током наведених месеци (април-мај) могли ближе да одредимо време похода. Наиме, палатин Виљема Другет 8. маја 1340. године у Вишеграду издаје судску повељу из које сазнајемо да су се пред њим 1. маја појавили три племића - Лукач, син Леринца, Петер, син Шебешћена, и Ласло, син Петера из Калуза (Kaluz-i; Фејерска жупанија) и, на другој страни Бенедек из Помаза, у судском поступку вођеном око спорног поседа Помаз (Pomaz). Палатин је на захтев обе стране одложио спор на 15 дана од повратка краљевске војске, ако се до тада стране не измире. ${ }^{11}$ На основу овог документа без сумње можемо констатовати да је Виљем 1. маја још увек делио правду на свом судском

\footnotetext{
${ }^{3}$ Antal Pór, Magyar-rutén érintkezések a XIV-ik században, Sz, 1904, 947.

${ }^{4}$ M. Wertner, Magyar hadjáratok, 436.

${ }^{5}$ М. Грушевський, Iсторія України-Руси, IV, 21, 435-436; Ставове Грушевског прихвата и Henryk Paszkiewicz, Polityka ruska Kazimierza Wielkiego, 53-55.

${ }^{6}$ Antoni Prochaska, W sprawi zajecia Rusi przez Kazimierza Wielkiego, Kwartalnik Historyczny (= KH), rocz. VI, 1892, 19-20; Омельян Терлецький, Політичні події на Галицкій Руси в р. 1340 по смерти Болеслава Юрия II, Записки НТШ, XII, 1896, 12.

${ }^{7}$ J. Dąbrowski, Ostatni lata Ludwika Wielkiego, 100.

${ }^{8}$ J. Wyrozumski, Kazimierz Wielki, 86-87.

${ }^{9}$ Anatol Lewicki, Jeszcze w kwestji zajęcia Rusi Czerwonej przez Kazimierza, KH, rocz. IX, 1895. 480-485.

${ }^{10}$ М. Волощук, А. Стасюк, Про похід палатина Віллерма, 48-49; Свој закључак о 19/20. априлу аутори изводе на основу (не баш најпрецизније) интерпретације једног судског документа судије краљевске курије Пала издатог 29. јануара 1341. године. Codex diplomaticus Hungariae ecclesiasticus ac civilis (ed. Georgius Fejér), Budapest 1829-1844 (= F), VIII/4, 551; Anjou-kori oklevéltár, Dokumenta res Hungaricas tempre regum Andegavensium illustrantia (Szerk. Kristó Gyula, etc.), Budapest-Szeged 1990- (= Anjou), XXV, ann. 1341, бp. 86.

${ }^{11}$ Anjou, XXIV, 1340, бp. 289.
} 
двору у Вишеграду - анжујској престоници Угарске, а да је његова канцеларија, формално у његовом присуству, а суштински, највероватније без његовог присуства, о томе издала документ 8. маја. Односно, да се почетком маја краљевска војска увелико већ спремала на поход, о чему говори и сам документ. Наравно, без Виљема угарски контингент није могао да крене у правцу Карпата, а то се збило после 1. односно 8. маја 1340. године. Могуће и из самог Вишеграда. Оно што је најважније, кључни извор за поход Виљема Другета in Ruteniam, документ краљевског судије Пала Нађмартонија (издат 15. маја, због одлагања парнице која је била заказана за 8. мај) у потпуности подржава овакав след догађаја. Коначно, исти краљевски судија је (8. маја), одложио још два судска спора заказана за 1. мај, управо због „краљевског похода“. Наиме, један документ, по налогу самог краља (ob perceptus domini regis), издао је Тамашу de Zech који је тужио три племића из Земплина, ${ }^{12}$ а други у случају спора који се односио на странке из жупаније Саболч, између извесног Миклоша, сина Иштвана, на једној страни и Ладислава, сина Михаља из породице Калаи (из рода Балог-Шемјен), и његовог фамилијара Миклоша на другој страни, које је пред судијом заступао Ладиславов син Петер. ${ }^{13}$

Угарско ратовање на тлу Галичко-волинске државе 1340. године имало је ограничено трајање. Антал Пор је својевремено написао, не наводећи изворе, да се овај поход убрзо и завршио. ${ }^{14}$ По нама, овај став је прихватљив и можемо га аргументовати. Формално гледано, распуштање ове угарске војске је уследило, како на основу више дипломатичких извора констатује Мор Вертнер, 1. јануара 1341. године. ${ }^{15}$ Али овде је реч била заправо о документима који формално констатују одржавање судских спорова, раније заказаних на уобичајених 15 дана од завршетка похода краљевске војске. Формално гледано, у судској пракси угарски краљевски походи су се током XIV века релативно често завршавали управо 1 . јануара. ${ }^{16} \mathrm{У}$ нашем случају, вредност ових докумената, који нажалост не говоре непосредно о походу, односи се првенствено на идентификацију његових могућих учесника. О тим племићима учесницима први је писао Антал Пор. На његово излагање вратићемо се у даљем излагању.

Виљем Другет, а са њиме и његове трупе из руске земље, вратио се најкасније до средине јуна 1340. године. Наиме, након паузе, палатина Другета 11. јуна поново налазимо у Вишеграду како дели правду. Тог дана, пред њим су се (coram nobis) због решавања спора око поседа Фелкезеу у жупанији Зала појавили веспримски каноник и декан Козма, као заступник веспримског бискупа, и „Paulus filius Bulchu“, као представник друге стране у спору. О исходу парнице палатин је 18. јуна у Вишеграду издао повељу. ${ }^{17}$

\footnotetext{
${ }^{12}$ A zichi és vásonkeői gróf Zichy-család idösb ágának okmánytára, I-XII, Pest, Budapest 1871-1931 (= Z), I, 578; Anjou, XXIV, 1340, бр. 292; Упор.: М. Wertner, Magyar hadjáratok, 436.

${ }^{13}$ A nagykállói Kállay-család levéltára (= Kállay), I, Budapest 1943, 136; Anjou, XXIV, 1340, бp. 291; Pál Engel, Magyarország világi archontológiája, I-II, Budapest 1996 (= P. Engel, Archontológia), II, 121.

${ }^{14}$ A. Pór, Magyar-rutén érintkezések, 947.

${ }^{15} \mathrm{M}$. Wertner, Magyar hadjáratok, 436.

${ }^{16}$ Imre Szentpétery, Oklevéltani naptár, Budapest 1912, 30-31.

${ }^{17}$ Zala vármegye története, Oklevéltar (Szerkesztik Nagy Imre, Véghely Dezső és Nagy Gyula) I, Budapest
} 
На основу свега, можемо закључити да је поход угарске војске in Ruteniam који је предводио Виљем Другет био започет после 1. маја 1340. године (datum post quem; највероватније између 1. и 8. маја) и да се Виљем Другет срећно вратио у Вишеград пре 11. јуна (datum ante quem). Ако одбијемо неопходне дане за одлазак и безбедан повратак преко Карпата угарских трупа и њихове коморе, уз процену да је једна таква војска успевала да превали 30 до 40 километара дневно, можемо опрезно претпоставити да је Другет у Галицији могао да ратује десетак дана. ${ }^{18}$ Остаће међутим питање какав војни успех су угарски витезови за то време постигли на тлу стране земље и да ли су се њихови одреди, и када, сјединили с трупама пољског краља Казимира. У једно можемо бити сигурни: како су већ аргументовано констатовали Мирослав Волошчук и Андреј Стасив, војни потенцијал војске коју је предводио палатин Виљем Другет могао је бити значајан.

Ако кренемо од палатинске породице Другет, морамо рећи да се под њиховом (не)посредном влашћу налазила цела североисточна Угарска (данас области североисточне Мађарске, источне Словачке, закарпатске Украјине). Сам Виљем је пред крај тридесетих година имао жупанску власт у десет жупанија (Спиш, Ујвар, Шариш, Земплин, Уж, Турња, Гемер, Боршод, Хевеш и Пешт), власништво над девет тамошњих тврђава, међу којима је било и Невицке код Ужгорода, и управу (кастеланство) над преко десет краљевских утврђења. Једном речју, власт и моћ као ниједан други угарски барон тог доба. Другети су заправо били најоданији пратиоци чланова анжујске династије још у Напуљу, а тиме и угарског краља Карла Роберта Анжуа (1301-1342) када је као младић стигао у Угарску. Када је Карло постао стварни господар Угарске, он је Другете уздигао на место најмоћније баронске породице у држави, чија су три члана, један за другим: Филип (1323-1327), његов старији брат Жан (1328-1334) и његов син Виљем (13341342), заузимала палатински положај. Родоначелник породице у Угарској, Виљемов стриц, а Карлов пратилац од најранијег детињства, Филип Другет, истицао се као један од најбољих краљевих војсковођа. Он је у име краља већ око 1316. године преузео контролу на североистоку државе и организовао снажну војску својих „фамилијара“ (exercitus magistri Philippi) која је током друге и треће деценије XIV века успешно ратовала против најмоћнијег угарског олигарха Матеја Чака, ишла на удаљене походе против српског краља Милутина (1319), у Хрватску против тамошњих непокорних великаша (1323), или пак у Влашку (1324). После Филипове смрти 1327. године, наследник његових огромних поседа и богатства братанац Виљем (од пролећа 1334, па до своје смрти, у септембру 1342 - такође палатин) наставио је витешку традицију свог стрица. ${ }^{19}$

1886, 367-368; Anjou, XXIV, 1340, бp. 396.

${ }^{18}$ Омељан Терлецкиј, који је био мишљења да је угарска војска кренула на поход 7. маја, сматрао је да је она могла да стигне на Рус око 15-20. маја. Упор. О. Терлецький, Політичні подіï, 12-13.

${ }^{19}$ Đura Hardi, Drugeti, povest o usponu i padu porodice pratilaca anžujskih kraljeva; Novi Sad 2012, passim. 
Тако је 1330. године, као спишки и ујварски жупан, предводио угарску војску која је учествовала на страни Карловог таста, пољског краља Владислава Ликјетка, у рату против Немачког витешког реда у Прусији. ${ }^{20}$ Некако би била логична помисао да је војска под заповедништвом Виљема Другета, 1330. и 1340. године располагала са приближно истим снагама. Захваљујући пре свега пруским хроничарима, о походу Виљема Другета из 1330. године сачуван је низ занимљивих података који би нам, на први поглед, могли бити од помоћи. Наиме, савременик догађаја, пруски писац Петер из Дусбурга (Peter von Dusburg) саопштава да је Виљемов угарски контингент 1330. године имао осам хиљада људи, док малопољски хроничар располаже бројем од десет хиљада угарских војника. ${ }^{21}$ Наравно, средњовековни писци су као по правилу преувеличавали бројност војски, али све у свему, Другет је 1330, а верујемо и 1340. године, био заповедник значајне силе. Усудићемо се претпоставити да ако би преко Карпата својим пољским савезницима Виљем довео око 500, могуће чак и 800 до 1.000 војника, војску састављену од искусних коњаника-витезова и пешака (заједно), за прилике ратовања XIV века то би била сила достојна сваког поштованња. Али то су само наше претпоставке.

На крају, слику о саставу Виљемове војске 1340. године делимично нам илуструју имена, највероватније могућих, учесника овог похода. О њима је први подробно писао већ помињани Антал Пор, а затим и други историчари, у најновије време Мирослав Волошчук и Андреј Стасјук. ${ }^{22}$ Дакле, уз палатина су, поуздано знамо, тог маја у походу на Галицију јахали: Петер, син Ладислава, и Ладислав, син Јаноша, из породице Розгоњи (de Rozgun), угледни потомци палатина Ренолда и поседници у Ујварској жупанији, ${ }^{23}$ затим сигурно и Тамаш, син Ладислава de Zeech, из моћног рода Бакша - власника Сечовца (Gálszécs) у Земплинској жупанији, а вероватно и други чланови ове бројне породице, ${ }^{24}$ Pete de Hassagh (Hasságh) из Спишке жупаније, ${ }^{25}$ изгледа и извесни comes Johannes dictus Zeuke (Zewke), заступник једне стране у судском спору пред викаром егерског бискупа који је одложен, како сазнајемо, због похода краљевске војске. Овај Johannes dictus Zeuke, по нама, највероватније је Јанош dictus Зонк, Виљемов „фамилијар“ и поджупан у Боршоду и Шаришу. Он и његов старији брат Балаш из породице Фоњи били су годинама у служби Другета, као њихови најоданији кастелани и жупани. ${ }^{26}$ По Анталу Пору, учешће су узели и чланови рода Текеле, као и рода Бастех. ${ }^{27}$ Текеле,

\footnotetext{
${ }^{20}$ Упор. Исто, 314-316.

${ }^{21}$ Chronicon terrae Prusiae von Peter von Dusburg, Scriptores rerum Prussicarum. Geschichtsquellen der preußischen Vorzeit, (1-5 Bde, Leipzig 1861-1874) II, 218; Rocznik Traski, Monumenta Poloniae historica (ed. August Bielowski, Nakł. Akademii Umiejętności), t. I-VI (Lwów-Kraków 1864-1893), репринт, Warszawa 1960-1961 (= MPH), II, 854; упор. и: Rocznik małopolski, MPH, III, 191.

${ }^{22}$ A. Pór, Magyar-rutén érintkezések, 947; M. Wertner, Magyar hadjáratok, 436; J. Dąbrowski, Ostatni lata Ludwika Wielkiego, 100; М. Волощук, А. Стасюк, Про похід палатина Віллерм, 46-54.

${ }^{23}$ A, IV, 26; A. Pór, Magyar-rutén érintkezések, 947.

${ }^{24}$ Z, I, 578; Anjou, XXIV, 1340, бp. 292; P. Engel, Archontológia, II, 235.

${ }^{25}$ F, VIII/4, 551; Anjou, XXV, 1341, бp. 86

${ }^{26}$ A nagykárolyi gróf Károlyi-család oklevéltára, I (ed. Kálmán Géresi), Budapest 1882, 138-139; P. Engel, Archontológia, II, 76; I, passim; Đ. Hardi, Drugeti, 131, 133, 135, 159, 162, 164, 167, 190, 255, $275-277$.

${ }^{27}$ A. Pór, Magyar-rutén érintkezések, 947.
} 
барем они из Шаришке жупаније, били су двадесетих година XIV века фамилијари Другета. ${ }^{28}$

Углавном, сви до сада наведени племићи имали су поседе на североистоку Угарске, у жупанијама где се простирала власт Другета. Неки од њих су очигледно били у непосредној служби Другета, а опет други су се одазвали да учествују у походу на позив самог владара попут чланова угледних породица Розгоњи или Бакша. Углавном, језгро војске Другета су, претпостављамо, чинили њихови фамилијари и ако се осврнемо на време Виљемовог стрица Филипа Другета, већ тада је породица имала на располагању знатну војну силу која је, на краљев позив, ратовала на удаљеним бојиштима изван тадашњих граница Угарске. Други део краљевске војске био је попуњен из области које нису потпадале под власт Другета. Један од барона који је учествовао у походу био је Тетеш Бечеи (de Bechey), жупан Барша и кастелан Леве, човек од великог поверења краљице Елизабете која је свакако имала интереса да помоћ њеном брату, пољском краљу, буде што већа. ${ }^{29}$ Вероватно су се у походу нашли и чланови породице Шембери (de Sember) из жупаније Хонт ${ }^{30}$ племићи из Саболчке жупаније (поджупан Ладислав, син Михаља из породице Калаи из рода Балог-Шемјен), ${ }^{31}$ као и извесни племићи из жупаније Темеш. ${ }^{32}$

Карло Роберт, који свакако није учествовао у овом походу ${ }^{33}$ заповедништво над војском је, верујемо не случајно, поверио управо свом палатину. За такав избор имао је низ разлога. За почетак, приличило је да заповедништво буде додељено палатину као краљевом највишем великодостојнику и заменику. Област државе којом је управљала породица Другет граничила се са Пољском и Галицијом и у техничком погледу најлакше је било да се одавде сакупи и покрене главнина краљевских снага, чије је језгро чинила војска „фамилијара“ породице Другет. Сам Виљем је попут свог стрица и оца био истински витез с богатим искуством и културом витешког понашања. Одрастао је на француском краљевском двору, вероватно био присутан и на анжујском двору у Напуљу. Лично је познавао пољског краља Казимира и његовог оца Владислава. Једном речју, од дана свог доласка у Угарску (око или пре 1327) постао је љубимац и најближи сарадник угарског краља. Коначно као заповедник угарске војске већ се био истакао у рату који је пољски краљ 1330. године водио против немачког витешког реда у Прусији. Пре свега као способан дипломата. Што се тиче Виљемовог, релативно кратког, војевања у Галицији 1340. године, немамо разлога да не верујемо да је оно било неуспешно. Барем немамо података о страдању угарске војске, а знамо да се Виљем ускоро сретно вратио у домовину и наставио своје државничке послове. Када 1342. године

\footnotetext{
${ }^{28}$ Đ. Hardi, Drugeti,106, 118, 151, 166-167.

${ }^{29}$ Z, I, 597.

${ }^{30}$ Z, I, 596; Anjou, XXV, 1341, бp. 47; A. Pór, Magyar-rutén érintkezések, 947.

${ }^{31}$ Kállay, I, Budapest 1943, 136; Anjou, XXIV, 1340, бp. 291; Engel, Archontológia, II, 121.

${ }^{32}$ Ortvay Tivadar, Temesvármegye és Temesvár város története, 4. köt, Oklevelek Temesvármegye és Temesvár város történetéhez (Gyûjt. Pesty Frigyes), I, Pozsony 1896, 65-69; Anjou, XXV, 1341, бp. 302.

${ }^{33}$ F. Šišić, Itinerarij Karla I, 142; М. Грушевський, Iсторія України-Pуси, IV, 436; Đ. Hardi, Drugeti, 338.
} 
умре Карло Роберт, а за њим и његов палатин Виљем, неке нове личности постаће актери угарске политике у борби за наследство Романовича.

\section{Извори и литература}

Извори:

A nagykállói Kállay-család levéltára, I, Budapest 1943.

A nagykárolyi gróf Károlyi-család oklevéltára (ed. Kálmán Géresi), I, Budapest 1882.

A zichi és vásonkeői gróf Zichy-család idősb ágának okmánytára, I-XII, Pest, Budapest 1871-1931.

Anjou-kori oklevéltár, Dokumenta res Hungaricas tempre regum Andegavensium illustrantia (Szerk.

Kristó Gyula, etc.), Budapest-Szeged, 1990- .

Anjoukori okmánytár, Codex diplomaticus Hungaricus Andegavensis (Szerkesztik Nagy, Imre, Tasnádi Nagy, Gyula), I-VII, Budapest 1878-1920.

Chronicon terrae Prusiae von Peter von Dusburg, Scriptores rerum Prussicarum. Geschichtsquellen der preußischen Vorzeit, 1-5 Bde, Leipzig 1861-1874.

Codex diplomaticus Hungariae ecclesiasticus ac civilis (ed. Georgius Fejér), Budapest 1829-1844.

Ortvay Tivadar, Temesvármegye és Temesvár város története, 4. köt, Oklevelek Temesvármegye és Temesvár város történetéhez (Gyüjt. Pesty Frigyes), I, Pozsony 1896.

Rocznik małopolski, Monumenta Poloniae historica (ed. August Bielowski), t. I-VI, (Lwów-Kraków 1864-1893), репринт, Warszawa 1960-1961.

Zala vármegye története, Oklevéltar (Szerkesztik Nagy Imre, Véghely Dezső és Nagy Gyula), I, Budapest 1886.

\section{Литература:}

Wertner, Mór, Magyar hadjáratok a XIV. században, Századok, 1905, 420-451.

Wyrozumski, Jerzy, Kazimierz Wielki, Wrocław-Warszawa-Kraków 2004.

Wojtowycz, Leontyj, Walka o spadek po Romanowiczach a król polski Kazimierz III Wielki, Kazimierz Wielki i jego państwo (ed. J. Maciejewski, T. Nowakowski), Bydgoszcz 2011, 47-66.

Волощук, Мирослав, Стасюк, Андрій, Про похід палатина Віллерма in Ruteniam у квітні 1340 $p$, Вісник Прикарпатського університету, Історія, Випуск 17, 1995, 46-54.

Грушевський, Михайло, Історія Украйни-Руси, III-IV, Київ 1993.

Dąbrowski, Jan, Ostatni lata Ludwika Wielkiego 1370-1382, Krakow 2009.

Engel Pál, Magyarország világi archontológiája, I-II, Budapest 1996.

Károly Róbert emlékezete (A szöveg anyagot válogatta, szerkesztette, a bevezetőt és a jegyzeteket írta Kristó Gyula és Makk Ferenc, A képanyagot Marosi Ernő válogatta), Budapest 1988.

Lewicki, Anatol, Jeszcze w kwestji zajęcia Rusi Czerwonej przez Kazimierza, Kwartalnik Historyczny, rocz. IX, 1895, 480-485.

Paszkiewicz, Henryk, Polityka ruska Kazimierza Wielkiego, Warszawa 1925.

Pór Antal, Magyar-rutén érintkezések a XIV-ik században, Sz, 1904, 937-949.

Prochaska, Antoni, W sprawi zajecia Rusi przez Kazimierza Wielkiego, Kwartalnik Historyczny, rocz. VI, 1892, 1-33.

Szentpétery Imre, Oklevéltani naptár, Budapest 1912. 
Терлецький, Омельян, Політичні подї на Галиикій Руси в р. 1340 по смерти Болеслава Юрия II, Записки НТШ, XII, 1896, 1-26.

Hardi, Đura, Drugeti, povest o usponu i padu porodice pratilaca anžujskih kraljeva, Novi Sad 2012. Šišić, Ferdo, Itinerarij Karla I (1301-1342), Vjesnik Kraljevskog-slavonsko-dalmatinskog Zemaljskog Arkiva, 1902, 131-143. 
ĐURA HARDI

\title{
THE CHRONOLOGY OF A CAMPAIGN OF PALATINE WILLIAM DRUGETH
}

\begin{abstract}
Summary
The paper examines the chronology of the campaign of the Hungarian palatine William Druget in the Galicia - Volynia principality of 1340. Being the cousin and ally of the Polish king Casmir III the Great, Hungarian King Charles Robert of Anjou in order to obtain the aforementioned Russian lands after the death of their ruler Yuri II Boleslav, undertook this campaign as a military aid to the Polish ruler. In addition, the author of the paper tries to determine the length of the Hungarian war on Russian soil, and possible strength of the Hungarian royal army under the command of one representative of the family Druget. Drugets were in fact, in previous decades commanders of the army in campaigns against Serbia, Croatia, and Prussia. Based on the analysis of data from published itinerary court charters, as well as from the itinerary of the Palatine himself, author of the paper comes to the following conclusion. The operation of the Hungarian army in Ruthenia, which was led by William Druget, had most likely started after 1 May 1340 (date post quem, most probably between 1 and 8 May) and the Druget returned to Visegrad before 11 June (date ante quem). If we reject the necessary days needed for Hungarian troops and their chambers to go and to safely return through the Carpathian Mountains, one can cautiously assume that Druget in Galicia could have actively been at war for about ten days. Considering the territory in northeastern Hungary which Druget family had ruled over and experience of their warriors, as well as the sporadically preserved names of possible participants in this campaign, it can be concluded that the army sent ,in Ruthenia“ had represented a significant military force.
\end{abstract}

Poland.

Keywords: William Drugeth, campaign 1340, Hungary, Galicia-Volhynia, 